\title{
Bilateral cortical necrosis of the kidneys following snakebite
}

\author{
T. VARAGUNAM \\ M.D., M.R.C.P. \\ Senior Lecturer in Medicine
}

\author{
R. G. PANABOKKe \\ M.D., Ph.D., M.C.Path. \\ Senior Lecturer in Pathology
}

Bilateral cortical necrosis of the kidneys is a rare pathological lesion. It usually follows some complication of pregnancy such as eclampsia. There has been only one case report where the lesion was seen at autopsy of a patient who died of uraemia after a snakebite (Azevedo \& Teixeira, 1938). Oram, Ross, Pell \& Winteler (1963) have described calcification of both renal cortices in a patient who recovered from anuria following a snakebite and they suggested that the calcification was due to bilateral cortical necrosis of the kidneys which had followed the bite.

The interesting feature in the present case report is the finding of extensive infiltration of fat in the structures within the areas of necrosis of both renal cortices.

\section{Case report}

A 30-year-old male was admitted to Kandy Hospital on 16 December 1967 complaining of not having passed urine for 16 days. On 1 December 1967 he was bitten by a snake on the left hand while working in a paddy field. There was pain and swelling on the left hand for 4 days following the bite. On the eighth day after the bite he had passed a few drops of red coloured urine. He did not have any epistaxis, haemoptysis or haematemesis. His stools had been of normal colour. Prior to admission to hospital he was treated at home by an Ayurvedic practitioner who had applied local herbs and oils to the wound. The patient had no major illness in the past and had worked as a manual labourer in the paddy fields all his life. There was nothing relevant in the family history. The snake that had bit him was identified by experts as a pit-viper (Agkistrodon hypnale) after studying the description of the reptile given by the patient and witnesses.

At the time of admission he was conscious and rational. There were recent scars of two fang marks on the dorsum of his left hand. There was no evidence of bleeding into the skin, conjunctivae, and mucous membranes of the mouth. The face was swollen and there was marked pitting oedema of both ankles. Temperature $37 \cdot 2^{\circ} \mathrm{C}$, pulse $84 / \mathrm{min}$, respirations were $24 / \mathrm{min}$. There was no cyanosis and no icterus.
BP $180 / 80 \mathrm{mmHg}$. JVP elevated to $10 \mathrm{~cm}$ above the sternal angle. No abnormal physical signs were detected over the precordium. A few medium crepitations were heard at both lung bases. The abdomen was clinically normal. There was marked tenderness over both loins. The central nervous system was clinically normal. There was no urine in the bladder on catheterization.

For the first $48 \mathrm{hr}$ following admission he was managed conservatively for anuria on the following regimen: $600 \mathrm{ml}$ of $30 \%$ dextrose orally for every 24 hr; benzylpenicillin $\frac{1}{2}$ million units i.m., b.d.; and soluble insulin 15 units s.c. for every $24 \mathrm{hr}$. He was not given antivenom. He died on the third day after admission, while having a peritoneal dialysis. He did not pass any urine during his stay in hospital. His blood pressure remained elevated around 180/80 until death.

Investigations on day of admission: Blood urea $216 \mathrm{mg} / 100 \mathrm{ml}$; serum sodium $132 \mathrm{mEq} / \mathrm{l}$; serum potassium $7.8 \mathrm{mEq} / \mathrm{l}$; plasma bicarbonate 11.8 $\mathrm{mEq} / \mathrm{l}$; serum proteins $6.8 \mathrm{~g} / 100 \mathrm{ml}$ (albumin $4 \mathrm{~g}$, globulins $2.8 \mathrm{~g}$ ); Hb $6.6 \mathrm{~g} / 100 \mathrm{ml}$; PCV $22 \%$; WBC $9000 / \mathrm{mm}^{3}$ (normal differential); bleeding time $5 \frac{1}{2} \mathrm{~min}$; clotting time $3 \mathrm{~min}$; ECG; sinus rhythm; tall $\mathrm{T}$ waves of hyperkalaemia.

Investigations on day of death: Blood urea 317 $\mathrm{mg} / 100 \mathrm{ml}$; serum sodium $102.5 \mathrm{mEq} / \mathrm{l}$; serum potassium $5.7 \mathrm{mEq} / \mathrm{l}$; plasma bicarbonate $9.3 \mathrm{mEq} / \mathrm{l}$.

\section{Necropsy}

(16 hr after death.) The body was well nourished and there was oedema of the ankles and sacral area. There was no evidence of bleeding into the skin. The kidneys were larger than normal and their capsules stripped easily. Their external surfaces were smooth and showed numerous areas of necrosis which were yellow in colour alternating with red haemorrhagic areas. In the cut surfaces the necrotic areas were found to be confined to the cortices (Fig. 1). A rim of cortical tissue 1-2 mm in thickness just beneath the renal capsule was undamaged. The medullae of both kidneys were congested. There were no abnormalities in the renal pelves. 


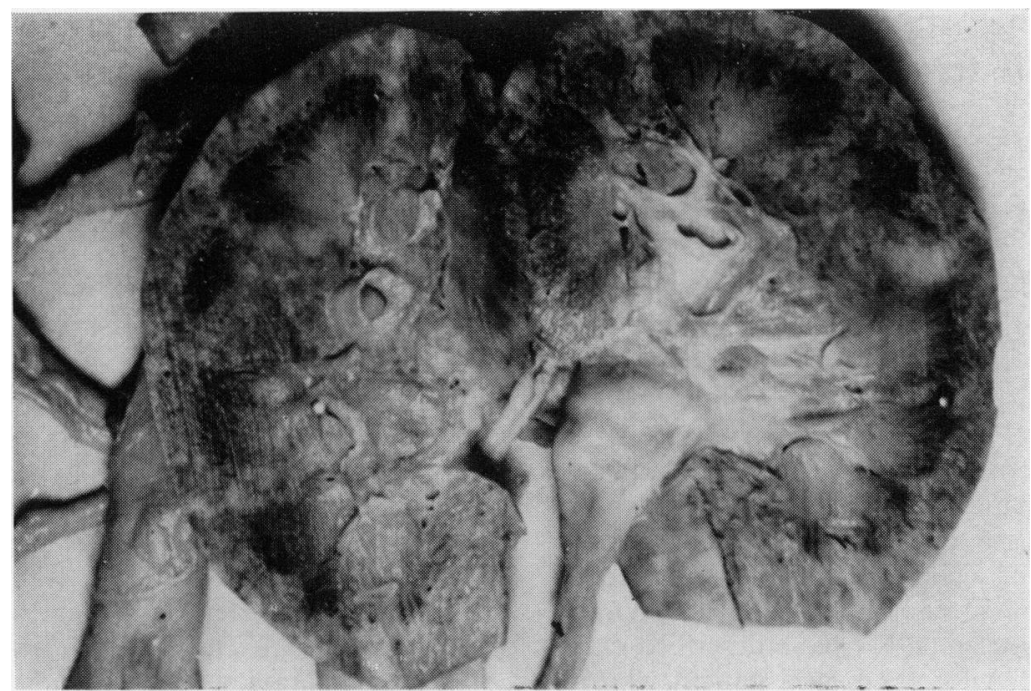

FIg. 1. Cut surface of kidney showing pale areas of necrosis in the cortex.

The heart, lungs, liver, spleen, adrenals and intestines were macroscopically normal. (Since there was a specific request by the relatives not to open the cranial cavity, the brain was not examined.)

\section{Histology}

The kidneys showed irregular areas of coagulative necrosis in their cortices. Both glomeruli and tubules were involved in the necrotic process. The majority of the glomeruli in these areas were totally necrosed, a few however showed only partial necrosis of the

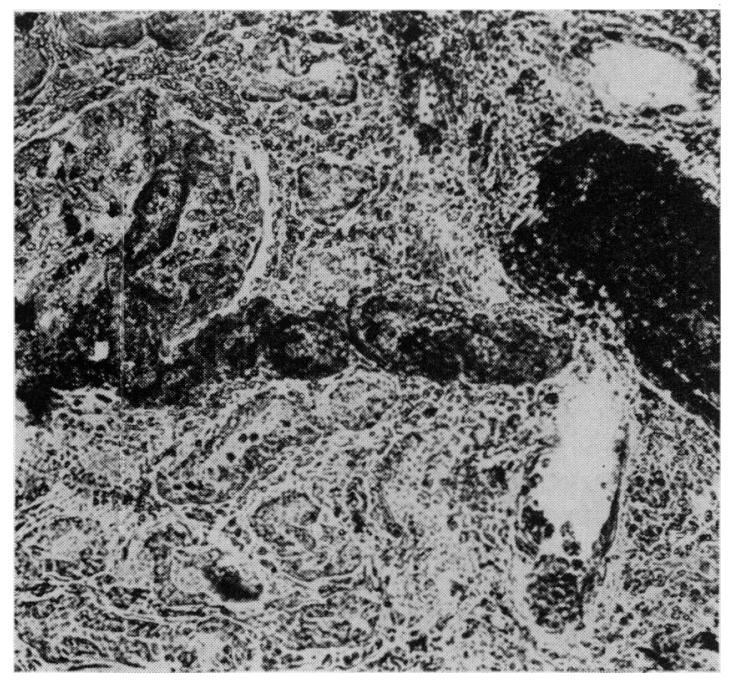

FIG. 2. Photomicrograph of renal cortex showing dark areas denoting the presence of fat in a glomerulus, its afferent arteriole and intralobular artery. Frozen section stained with Sudan 111, $\times 90$. glomerular tufts. Only a few of the affected glomeruli showed haemorrhage into the glomerular tufts and Bowman's capsular space. An infiltrate consisting of both acute and chronic inflammatory cells was seen surrounding the necrotic areas. Within the lumina of some renal tubules there was eosinophilic material which was consistent with coagulated protein; in others there was acute inflammatory exudate. Necrosis was seen in many intralobular arteries and afferent arterioles. In some of the necrosed intralobular arteries there was superadded thrombosis. A thin rim of cortical tissue beneath the renal capsule was not necrosed.

In frozen sections stained for fat, sudanophilic material was present in the walls and lumina of the intralobular arteries, afferent arterioles and glomerular capillaries (Fig. 2). Similar sudanophilic material was seen in the walls and lumina of the tubules and intertubular vessels within the areas of necrosis.

The liver showed early fatty change. Portions of the lung showed bronchopneumonia. The heart, spleen, adrenals and intestines were normal.

\section{Discussion}

Snake venom is well known to cause toxic damage to the kidneys (Schreiner \& Maher, 1965). Acute renal failure is one of the clinical manifestations that may result from this toxicity. Table 1 summarizes the pathological lesions in the kidneys which have been previously reported in those patients who developed acute renal failure after snakebite.

Bilateral cortical necrosis of the kidneys was first described by Juhel-Renoy (1886). The lesion is characterized by an acute necrosis of large portions of the renal cortices. The medulla and a few milli- 
TABLE 1. Previously reported pathological lesions in the kidneys of patients who had acute renal failure after snake-bite

\begin{tabular}{|c|c|c|c|}
\hline Author & $\begin{array}{l}\text { Number of } \\
\text { patients }\end{array}$ & Snake & Pathology \\
\hline Amorim \& Mello (1954) & 3 & $\begin{array}{l}\text { Rattlesnake } \\
\text { (Crotalus terrificus } \\
\text { terrificus) }\end{array}$ & Necrosis of distal tubules (autopsy) \\
\hline Azevedo \& Teixeira (1938) & 1 & $\begin{array}{l}\text { Cobra } \\
\text { (Bothrops jararaca) }\end{array}$ & $\begin{array}{l}\text { Glomerulonephritis } \\
\text { Vascular necrosis (autopsy) }\end{array}$ \\
\hline Efrati \& Reif (1953) & 4 & ? Palestinian viper & $\begin{array}{l}\text { Glomeruli stuffed with red cells } \\
\text { (autopsy) }\end{array}$ \\
\hline $\begin{array}{l}\text { Marsden \& Reid (1961) } \\
\text { Oram et al. (1963) }\end{array}$ & $\begin{array}{l}3 \\
1\end{array}$ & $\begin{array}{l}\text { Sea-snake } \\
\text { Sand-viper } \\
\text { (Echis carinatus) }\end{array}$ & $\begin{array}{l}\text { Necrosis of distal tubules (autopsy) } \\
\text { Calcific material, shrunken glomeruli } \\
\text { with thick capsules, dense infiltrate of } \\
\text { mononuclear cells (kidney biopsy) }\end{array}$ \\
\hline
\end{tabular}

metres of cortical tissue just beneath the renal capsule escape necrosis. The necrosis is ischaemic in origin. The causation of the ischaemia is uncertain. The theories that have been postulated to explain the ischaemia have been reviewed by Duff \& Murray (1941) and Lauler \& Schreiner (1958).

The renal lesion in our patient must have occurred soon after the bite, because the anuria commenced on the day that he was bitten. Could the venom have caused direct toxic damage to the smaller blood vessels in the kidneys? If the venom had been rapidly absorbed into the blood stream, a very high concentration of it would have been present in the renal tissues, because among the large organs of the body the kidneys receive the largest amount of blood per unit weight of tissue (Starling \& Lovatt Evans, 1962). Vasculotoxic properties are present in the venom of the Viperidae (Reid, 1968). It is probable that vascular necrosis occurs only when the tissue concentrations of venom rise to the level that prevails in the kidneys, because we could not find any evidence of vascular necrosis in the other organs that weexamined.

It is difficult to explain the presence of fat in the blood vessels of the kidneys. A similar presence of fat was noted in a few cases of bilateral cortical necrosis of the kidneys which supervened on pregnancy (Scriver \& Ortel, 1930; Warner \& Hibbits, 1932). Scriver \& Ortel (1930) suggested that the intravascular fat was due to the hyperlipaemia that usually occurs with pregnancy. If this hypothesis were true it would be worthwhile estimating the blood lipids of patients who suffer from the ill-effects of snakebite. We have not estimated the blood lipids in our patient and we have not come across any reports of blood lipid changes in patients who were bitten by snakes. However, one might expect some changes in the blood lipids, since the enzyme phospholipase A has been demonstrated in most snake venoms (Bucherl, Buckley \& Deulofeu, 1968).

The blood pressure in our patient remained elevated until the time of death. This observation is interesting in the light of work done by Reid \&
Jenkins (1948) who showed that cobra venom was capable of releasing renin by acting directly on the kidneys of adrenalectomized rats.

\section{Acknowledgments}

We thank Professor G. E. Tennekon and Professor A. S. Dissanaike for their helpful criticism.

\section{References}

Amorim, M.F \& Mello, R.F. (1954) Intermediate nephron nephrosis from snake poisoning in man. American Journal of Pathology, 30, 479.

Azevedo, P.A. \& TeixeirA, De C.J. (1938) Intoxicacao pa veneno de cobra necrose symmetrica da cortex renal uremia. Memorias do Instituto Oswaldo Cruz, 33, 23.

BuCherl, W., BuCKLey, E. \& DeulofeU, V. (1968) Venomous Animals and their Venoms. Vol. 1, p. 183. Academic Press, New York.

DufF, G.L. \& MurRaY, E.G.D. (1941) Bilateral cortical necrosis of the kidneys. American Journal of Medical Sciences, 201, 428.

Efrati, P. \& ReIf, L. (1953) Clinical and pathological observations on sixty five cases of viper bite in Israel. American Journal of Tropical Medicine and Hygiene, 2, 1085.

Juhel-Renoy, E. (1886) De l'annurie precoce scarletinuese. Archives générales de Médicine, 1, 385.

LAULER, D.P. \& SCHREINER, G.E. (1958) Bilateral renal cortical necrosis. American Journal of Medicine. 24, 519.

Marsden, A.T.H. \& ReID, H.A. (1961) Pathology of seasnake poisoning. British Medical Journal, 1, 1290.

Oram, S., Ross, G., Pell, L. \& Winteler, J. (1963) Renal cortical calcification after snake-bite. British Medical Journal, 1, 1647.

ReID, H.A. (1968) Snakebite in the tropics. British Medical Journal, 3, 359.

ReID, H.A. \& Jenkins, G. (1948) The liberation of renin from the kidney by tissue injury with cobra venom. Australian Journal of Experimental Biology and Medical Science, 26, 215.

Schreiner, G.E. \& Maher, J.F. (1965) Toxic nephropathy. American Journal of Medicine, 38, 409.

SCRIVER, W. DE M. \& ORTEL, H. (1930) Necrotic sequestration of the kidneys in pregnancy. (Symmetrical cortical necrosis.) Journal of Pathology and Bacteriology, 33, 1071.

Starling, E.H. \& Lovatt Evans, C. (1962) Principles of Human Physiology, 13th Edn. p. 210. Churchill, London.

WARNER, C.G. \& HibBITs, J.T. (1932) Symmetrical cortical necrosis of the kidneys in pregnancy. American Journal of Obstetrics and Gynecology, 23, 875. 